\title{
Spectroscopic, thermal and magnetic properties of some transition metal complexes derived from 1-Phenyl-3-Substituted-4-Nitroso-5-Pyrazolones
}

\author{
Samir A. Abdel-Latif ${ }^{1 *}$, Yousry M. Issa ${ }^{2}$ \\ ${ }^{1}$ Chemistry Department, Faculty of Science, Helwan University, Helwan, Egypt; *Corresponding Author: salatif $1 @$ yahoo.com \\ ${ }^{2}$ Chemistry Department, Faculty of Science, Cairo University, Giza, Egypt
}

Received 25 June 2010; revised 28 July 28 2010; accepted 5 August 2010.

\begin{abstract}
Complexes derived from some 1-Phenyl-3-methyl-4-nitroso-5-pyrazolone (L1), 1,3-diphenyl-4nitroso-5-pyrazolone (L2) and 1-phenyl-3-anilino4-nitroso-5-pyrazolone (L3) with $\mathrm{Mn}^{2+}, \mathrm{Co}^{2+}, \mathrm{Ni}^{2+}$, $\mathrm{Cu}^{2+}$ and $\mathrm{Zn}^{2+}$ metal ions have been prepared. Structural investigation of the ligands and their complexes has been made based on elemental analysis, infrared (FT-IR), ultraviolet and visible spectra (UV-Vis.), proton nuclear magnetic resonance ( ${ }^{1} H$ NMR), magnetic susceptibility $\left(\mu_{\text {eff. }}\right)$ and thermal analysis (TG and DTG). The effect of solvents has been carried out in organic solvents of varying polarity. The observed transition energy and oscillator strengths were also calculated. The data obtained show that all of the prepared complexes contain water molecules in their coordination sphere. The investigated ligands acts as neutral bidentate ligands bonded to the metal ions through the two oxygen atoms of the carbonyl and nitroso groups. The isolated complexes behave as non-electrolyte in DMF solution. The $\mathrm{Mn}^{2+}, \mathrm{Co}^{2+}, \mathrm{Ni}^{2+}$ and $\mathrm{Cu}^{2+}$ complexes show high spin configurations as the ground state. The high spin values of magnetic susceptibility may be due to the ligands being weak ligands. The $\mathrm{Mn}^{2+}, \mathrm{Co}^{2+}, \mathrm{Ni}^{2+}, \mathrm{Cu}^{2+}$ and $\mathrm{Zn}^{2+}$ complexes exhibit an octahedral or distorted octahedral coordination with the investigated ligands.
\end{abstract}

Keywords: Nitrosopyrazolones; Transition Metal Complexes; Spectroscopic; Thermal; Magnetic studies

\section{INTRODUCTION}

Pyrazolones and their pyrazol derivatives are formed by the reaction between hydrazines and $\beta$-keto esters e.g. 3-methy-1-phenylpyrazolone was prepared from phenylhydrazine and ethyl acetoacetate. This on methylation gives antipyrine which is used in medicine as an antipyretic [1]. Nitrosopyrazolones are used as analytical reagents. Pyrazolone derivatives are capable of forming complexes with a large number of transition metal ions [2-5]. The formed complexes are characterized by their high stability due to the formation of six-membered rings. 4-Nitroso-2-pyrazolin-5-one derivatives have significant activity against Pyricularia oryzae [6,7]. Complexation behaviour of 4-hydroxy-2,2,6,6-tetramethylpipridine-1-oxyl, oximido-benzotetronic acid and 4-nitroso3-methyl-1-phenyl-2-pyrazoline-5-one each containing the same NO coordination group was complexed with some transition metal ions [8]. 1,3-Dimethyl-4-nitrosopyrazol-5-ol dissolved in methanol or DMSO together with small amount of $\mathrm{H}_{2} \mathrm{O}_{2}$ gives rise to nitroxide radicals when irradiated by UV light [9]. Nitrosation at C-4 of 1-n-alkyl-3-methyl-5-pyrazolone was achieved with sodium nitrite in hydrochloric acid medium. A tautomeric equilibrium in solution with a proton moving from $\mathrm{OH}$ at C-5 to nitrosated pyrazolones was proposed [10]. The structure and relative stabilities of the tautomers and isomers of 4-nitroso-pyrazolones were investigated at HF, DFT and MPn $(\mathrm{n}=2,4)$ quantum chemical levels. ${ }^{1} \mathrm{H},{ }^{13} \mathrm{C}$ and ${ }^{15} \mathrm{~N}$ NMR chemical shielding and coupling constants were calculated [11].

The present study deals with the preparation of $\mathrm{Mn}^{2+}$, $\mathrm{Co}^{2+}, \mathrm{Ni}^{2+}, \mathrm{Cu}^{2+}$ and $\mathrm{Zn}^{2+}$ complexes with the investigated ligands (L1-L3). The complexes obtained were subjected to many analytical tools such as elemental analysis, infrared (FT-IR), thermogravimetric (TG) and derivative thermogravimetric analysis (DTG), molar conductance, magnetic susceptibility $\left(\mu_{\text {eff. }}\right)$ and electronic spectra to throw some light on the bonds formed and on their structure. 


\section{EXPERIMENTAL}

All chemicals used in this work were chemically pure, obtained from $\mathrm{BDH}$ chemicals. They include $\mathrm{MnCl}_{2}$. $4 \mathrm{H}_{2} \mathrm{O}, \mathrm{CoCl}_{2} \cdot 6 \mathrm{H}_{2} \mathrm{O}, \mathrm{NiCl}_{2} \cdot 6 \mathrm{H}_{2} \mathrm{O}, \mathrm{CuCl}_{2} \cdot 2 \mathrm{H}_{2} \mathrm{O}$ and $\mathrm{ZnCl}_{2}$, $\mathrm{NH}_{4} \mathrm{OH}$, sodium nitrite, ethyl acetoacetate, phenylhydrazine, ethyl benzoylacetate, 1-phenyl-3-amino-5-pyrazolone, aniline, sodium ethoxide, ethyl cyanoacetate. The solvents used were methanol, ethanol, deutrated dimethyl sulfoxide ( $\mathrm{d}_{6}$-DMSO), dimethyl formamide (DMF), chloroform, cyclohexane, isopropanol, dioxane, hydrochloric acid and sodium hydroxide.

\subsection{Synthesis of the Ligands}

The 1-phenyl-3-methyl-5-pyrazolone was prepared from ethyl acetoacetate and phenylhydrazine according to the method described by Vogel [12], m.p. $127^{\circ}$ C. 1,3-Diphenyl-5-pyrazolone was prepared from ethyl benzoylacetate and phenylhydrazine [12]. 1-Phenyl-3-anilino5 -pyrazolone was obtained by the method described by Weissberger [13] from a mixture of 1-phenyl-3-amino-5pyrazolone and aniline, m.p. $221^{\circ} \mathrm{C}$. The investigated ligands were prepared [14] as follows, the nitrosation reactions were carried out by acidifying the cold aqueous solution of 1-phenyl-3-substituted-5-pyrazolone derivatives $(0.1 \mathrm{~mol})$ at $0^{\circ} \mathrm{C}$ in sodium hydroxide solution containing equivalent amount of sodium nitrite $(0.1 \mathrm{~mol})$ with hydrochloric acid. The precipitated ligands were filtered off, washed several times with water and recrystallized from ethanol. The purity of the compounds was determined from the results of elemental analysis and are summarized in Table 1, IR and ${ }^{1} \mathrm{H}$ NMR spectra. The resulting ligands have the following general formulae:

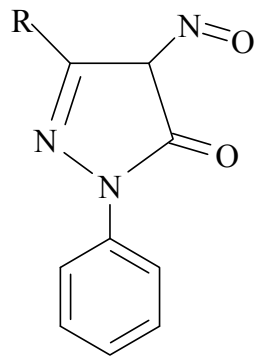

where $\mathrm{R}=\mathrm{CH}_{3^{-}}$, (1-phenyl-3-methyl-4-nitroso-5-pyrazolone), (L1)

$\mathrm{R}=\mathrm{C}_{6} \mathrm{H}_{5^{-}}$, (1,3-diphenyl-4-nitroso-5-pyrazolone), (L2)

$\mathrm{R}=\mathrm{C}_{6} \mathrm{H}_{5}-\mathrm{NH}-$, (1-phenyl-3-anilino-4-nitroso-5-pyrazolone), (L3)

\subsection{Synthesis of the Complexes}

The 1:1 or 1:2 complexes were prepared by mixing a hot alcoholic solution of the investigated ligands $(0.001$ or $0.002 \mathrm{~mol})$ with the calculated $(0.001 \mathrm{~mol})$ of metal salt solution. The reaction mixture was refluxed for $4 \mathrm{~h}$. The $\mathrm{pH}$ of the solution was maintained at a value of 5.0-6.0 by the addition of dilute ammonia solution (1:10). The solid complexes were dried on a steam bath with stirring, then filtered off and washed several times with ethanol-water mixture, $(1: 1 \mathrm{v} / \mathrm{v})$ till a colorless filtrate was obtained. The solid complexes were dried by suction and finally kept in vacuum desiccators.

\subsection{Physical Measurements}

The FT-IR spectra were recorded in the range 4000-400 $\mathrm{cm}^{-1}$ on a Jasco FT-IR spectrophotometer as $\mathrm{KBr}$ discs. The NMR spectra were measured using Varian Gemini 200-200 MHz spectrometer and the spectra were recorded from 0-15 ppm using TMS as an internal standard in dimethylsulfoxide $\left(\mathrm{d}_{6}\right.$-DMSO) as the solvent. Thermal analyses (TG and DTG) were obtained in a nitrogen atmosphere using a type TGA 50 of Shimadzu derivatograph thermal analyzer. The molar conductivities were carried out using a Jenway 4310 conductivity meter. Electronic spectra were recorded in the range 200-800 nm, on Jasco V-530 UV-Vis. spectrophotometer. Magnetic susceptibility values were obtained at room temperature using magnetic susceptibility balance (Sherwood scientific), Cambridge Science Park, Cambridge, England.

\section{RESULTS AND DISCUSSION}

\subsection{Characterization of the Ligands}

The structures of the investigated ligands (L1-L3) were established by the use of elemental analysis in Table 1, IR, UV-Vis and ${ }^{1} \mathrm{H}$ NMR spectra.

\subsubsection{Infrared Studies}

The infrared spectra of the investigated ligands and the most important IR band assignments that affect the structural features are listed in Table 2. The $v \mathrm{NH}$ appears as a medium broad one at $3210 \mathrm{~cm}^{-1}$ for ligand L3 . The band appearing at 1705, 1678 and $1688 \mathrm{~cm}^{-1}$ are ascribed to the stretching frequency of the $\mathrm{C}=\mathrm{O}$ group for ligands L1-L3, respectively. The band observed within the range $1410-1359 \mathrm{~cm}^{-1}$ assigned to $v \mathrm{~N}=\mathrm{O}$ [14].

\subsection{2. ${ }^{1} \mathrm{H}$ NMR Spectra}

The different types of protons in DMSO of the investigated ligands (L1-L3) were obtained. The spectra of the ligands L1-L3 exhibit a sharp singlet signal at $2.23 \mathrm{ppm}$. This signal is assigned to the aliphatic proton at position number $4[15,16]$ as shown in Figure: 
Table 1. Elemental analyses and magnetic moments for $\mathrm{Mn}^{2+}, \mathrm{Co}^{2+}, \mathrm{Ni}^{2+}, \mathrm{Cu}^{2+}$ and $\mathrm{Zn}^{2+}$ complexes with the investigated ligands (L1-L3).

\begin{tabular}{|c|c|c|c|c|c|c|c|c|c|}
\hline $\begin{array}{l}\text { Ligands and } \\
\text { Complexes }\end{array}$ & Tentative Formula & $\mathrm{M}: \mathrm{L}$ & $\mathrm{m} . \mathrm{p}^{\circ} \mathrm{C}$ & $\mathrm{C}$ & $\mathrm{H}$ & $\begin{array}{c}\% \text { Calculated } \\
\mathrm{N}\end{array}$ & $\begin{array}{c}\text { (found) } \\
\mathrm{Cl}\end{array}$ & M & $\mu_{\text {eff. }}$ \\
\hline L1 & $\mathrm{C}_{10} \mathrm{H}_{9} \mathrm{~N}_{3} \mathrm{O}_{2}$ & -- & 155 & $59.11(59.3)$ & $4.43(4,2)$ & $20.68(20.4)$ & -- & -- & -- \\
\hline L2 & $\mathrm{C}_{15} \mathrm{H}_{11} \mathrm{~N}_{3} \mathrm{O}_{2}$ & -- & 235 & $67.64(67.8)$ & $4.15(4.5)$ & $15.84(15.6)$ & -- & -- & -- \\
\hline L3 & $\mathrm{C}_{15} \mathrm{H}_{12} \mathrm{~N}_{4} \mathrm{O}_{2}$ & -- & 241 & $64.28(64.2$ & $4.24(4.3)$ & $20.00(19.8)$ & -- & -- & -- \\
\hline Mn-L1 & {$\left[\mathrm{MnC}_{10} \mathrm{H}_{21} \mathrm{~N}_{3} \mathrm{O}_{8} \mathrm{Cl}_{2}\right]$} & $1: 1$ & 325 & $27.52(27.5)$ & $4.81(4.3)$ & $9.63(9.4)$ & $16.05(16.3)$ & $12.59(13.0)$ & 5.94 \\
\hline Mn-(L1)2 & {$\left[\mathrm{MnC}_{20} \mathrm{H}_{20} \mathrm{~N}_{6} \mathrm{O}_{6}\right]$} & $1: 2$ & 330 & $48.49(48.2)$ & $4.04(3.9)$ & $16.97(17.2)$ & -- & $11.09(10.8)$ & 5.86 \\
\hline Co-L1 & {$\left[\mathrm{CoC}_{10} \mathrm{H}_{15} \mathrm{~N}_{3} \mathrm{O}_{5} \mathrm{Cl}_{2}\right]$} & $1: 1$ & 345 & $31.09(30.9)$ & $3.88(3.7)$ & $10.88(11.1)$ & $18.13(18.5)$ & $15.26(14.9)$ & 3.91 \\
\hline Co-(L1)2 & {$\left[\mathrm{CoC}_{20} \mathrm{H}_{24} \mathrm{~N}_{6} \mathrm{O}_{8}\right]$} & $1: 2$ & 344 & $44.86(44.4)$ & $4.48(4.5)$ & $15.70(15.9)$ & -- & $11.01(10.9)$ & 3.98 \\
\hline Ni-L1 & {$\left[\mathrm{NiC}_{10} \mathrm{H}_{29} \mathrm{~N}_{3} \mathrm{O}_{12} \mathrm{Cl}_{2}\right]$} & $1: 1$ & 343 & $23.45(23.2)$ & $5.66(5.8)$ & $8.20(8.4)$ & $13.67(13.8)$ & $11.47(11.1)$ & 3.12 \\
\hline $\mathrm{Ni}-(\mathrm{L} 1) 2$ & {$\left[\mathrm{NiC}_{20} \mathrm{H}_{22} \mathrm{~N}_{6} \mathrm{O}_{7}\right]$} & $1: 2$ & 335 & $46.44(46.4)$ & $4.25(4.1)$ & $16.25(16.2)$ & -- & $11.36(11.4)$ & 3.10 \\
\hline $\mathrm{Cu}-\mathrm{L} 1$ & {$\left[\mathrm{CuC}_{10} \mathrm{H}_{17} \mathrm{~N}_{3} \mathrm{O}_{6} \mathrm{Cl}_{2}\right]$} & $1: 1$ & 305 & $29.37(28.9)$ & $4.16(4.3)$ & $10.28(10.4)$ & $17.13(16.9)$ & $15.54(15.8)$ & 1.99 \\
\hline $\mathrm{Cu}-(\mathrm{L} 1) 2$ & {$\left[\mathrm{CuC}_{20} \mathrm{H}_{26} \mathrm{~N}_{6} \mathrm{O}_{9}\right]$} & $1: 2$ & 343 & $43.04(43.2)$ & $4.66(4.2)$ & $15.06(15.2)$ & -- & $11.39(11.5)$ & 2.10 \\
\hline Zn-L1 & {$\left[\mathrm{ZnC}_{10} \mathrm{H}_{15} \mathrm{~N}_{3} \mathrm{O}_{5} \mathrm{Cl}_{2}\right]$} & $1: 1$ & 335 & $30.58(30.7)$ & $3.82(3.9)$ & $10.70(10.9)$ & $17.83(17.9)$ & $16.66(16.8)$ & -- \\
\hline $\mathrm{Zn}-(\mathrm{L} 1) 2$ & {$\left[\mathrm{ZnC}_{20} \mathrm{H}_{22} \mathrm{~N}_{6} \mathrm{O}_{7}\right]$} & $1: 2$ & 355 & $45.85(45.9)$ & $4.20(4.1)$ & $16.04(16.3)$ & -- & $12.49(12.8)$ & -- \\
\hline Mn-L2 & {$\left[\mathrm{MnC}_{15} \mathrm{H}_{19} \mathrm{~N}_{3} \mathrm{O}_{6} \mathrm{Cl}_{2}\right]$} & $1: 1$ & 342 & $38.96(38.5)$ & $4.11(4.0)$ & $9.09(8.9)$ & $15.15(15.3)$ & 11.88 (11.7) & 5.84 \\
\hline $\mathrm{Mn}-(\mathrm{L} 2) 2$ & {$\left[\mathrm{MnC}_{30} \mathrm{H}_{28} \mathrm{~N}_{6} \mathrm{O}_{8}\right]$} & $1: 2$ & 320 & $54.97(55.1)$ & $4.27(4.4)$ & $12.82(12.8)$ & -- & $8.38(8.6)$ & 5.66 \\
\hline Co-L2 & {$\left[\mathrm{CoC}_{15} \mathrm{H}_{17} \mathrm{~N}_{3} \mathrm{O}_{5} \mathrm{Cl}_{2}\right]$} & $1: 1$ & 328 & $40.18(40.4)$ & $3.97(3.6)$ & $9.37(9.2)$ & $15.62(15.4)$ & $13.15(12.8)$ & 3.81 \\
\hline Co-(L2)2 & {$\left[\mathrm{CoC}_{30} \mathrm{H}_{28} \mathrm{~N}_{6} \mathrm{O}_{8}\right]$} & $1: 2$ & 335 & $54.63(54.6)$ & $4.24(4.4)$ & $12.74(12.5)$ & -- & $8.93(8.7)$ & 3.78 \\
\hline Ni-L2 & {$\left[\mathrm{NiC}_{15} \mathrm{H}_{17} \mathrm{~N}_{3} \mathrm{O}_{5} \mathrm{Cl}_{2}\right]$} & $1: 1$ & 350 & $40.20(40.6)$ & $3.79(3.9)$ & $9.38(9.5)$ & $15.63(15.7)$ & $13.11(13.4)$ & 2.99 \\
\hline $\mathrm{Ni}-(\mathrm{L} 2) 2$ & {$\left[\mathrm{NiC}_{30} \mathrm{H}_{28} \mathrm{~N}_{6} \mathrm{O}_{8}\right]$} & $1: 2$ & 337 & $54.65(54.7)$ & $4.25(4.4)$ & $12.75(13.1)$ & -- & $8.91(8.6)$ & 3.00 \\
\hline $\mathrm{Cu}-\mathrm{L} 2$ & {$\left[\mathrm{CuC}_{15} \mathrm{H}_{17} \mathrm{~N}_{3} \mathrm{O}_{5} \mathrm{Cl}_{2}\right]$} & $1: 1$ & 281 & $39.77(39.8)$ & $3.75(3.9)$ & $9.28(9.4)$ & $15.46(15.7)$ & $14.03(14.4)$ & 2.05 \\
\hline $\mathrm{Cu}-(\mathrm{L} 2) 2$ & {$\left[\mathrm{CuC}_{30} \mathrm{H}_{26} \mathrm{~N}_{6} \mathrm{O}_{7}\right]$} & $1: 2$ & 290 & $55.77(55.4)$ & $4.02(4.1)$ & $13.01(13.1)$ & -- & $9.83(9.9)$ & 1.98 \\
\hline $\mathrm{Zn}-\mathrm{L} 2$ & {$\left[\mathrm{ZnC}_{15} \mathrm{H}_{17} \mathrm{~N}_{3} \mathrm{O}_{5} \mathrm{Cl}_{2}\right]$} & $1: 1$ & 355 & $39.61(39.4)$ & $3.74(3.8)$ & $9.24(9.4)$ & $15.40(15.6)$ & $14.39(14.5)$ & -- \\
\hline $\mathrm{Zn}-(\mathrm{L} 2) 2$ & {$\left[\mathrm{ZnC}_{30} \mathrm{H}_{28} \mathrm{~N}_{6} \mathrm{O}_{8}\right]$} & $1: 2$ & 334 & $54.10(54.3)$ & $4.20(4.3)$ & $12.62(12.7)$ & -- & $9.82(9.7)$ & -- \\
\hline Mn-L3 & {$\left[\mathrm{MnC}_{15} \mathrm{H}_{28} \mathrm{~N}_{4} \mathrm{O}_{10} \mathrm{Cl}_{2}\right]$} & $1: 1$ & 341 & $32.79(32.6)$ & $5.10(5.3)$ & $10.20(9.9)$ & $12.75(13.2)$ & $10.00(9.8)$ & 5.74 \\
\hline Mn-(L3)2 & {$\left[\mathrm{MnC}_{30} \mathrm{H}_{30} \mathrm{~N}_{8} \mathrm{O}_{8}\right]$} & $1: 2$ & 327 & $52.56(52.6)$ & $4.38(4.9)$ & $16.35(17.2)$ & -- & $8.01(7.82$ & 5.86 \\
\hline Co-L3 & {$\left[\mathrm{CoC}_{15} \mathrm{H}_{20} \mathrm{~N}_{4} \mathrm{O}_{6} \mathrm{Cl}_{2}\right]$} & $1: 1$ & 348 & $37.42(37.7)$ & $4.15(4.3)$ & $11.64(11.9)$ & $14.55(14.8)$ & $12.24(12.4)$ & 3.87 \\
\hline Co-(L3)2 & {$\left[\mathrm{CoC}_{30} \mathrm{H}_{26} \mathrm{~N}_{8} \mathrm{O}_{5} \mathrm{Cl}_{2}\right]$} & $1: 2$ & 345 & $50.92(50.6)$ & $3.67(3.4)$ & $15.84(15.9)$ & $9.90(9.8)$ & $8.33(8.1)$ & 3.91 \\
\hline Ni-L3 & {$\left[\mathrm{NiC}_{15} \mathrm{H}_{16} \mathrm{~N}_{4} \mathrm{O}_{4} \mathrm{Cl}_{2}\right]$} & $1: 1$ & 345 & $40.47(40.3)$ & $3.59(3.3)$ & $12.59(13.4)$ & $15.74(16.3)$ & $13.19(12.7)$ & 2.90 \\
\hline $\mathrm{Ni}-(\mathrm{L} 3) 2$ & {$\left[\mathrm{NiC}_{30} \mathrm{H}_{36} \mathrm{~N}_{8} \mathrm{O}_{10} \mathrm{Cl}_{2}\right]$} & $1: 2$ & 335 & $45.18(45.6)$ & $4.51(4.6)$ & $14.05(13.9)$ & $8.78(9.5)$ & $7.36(6.9)$ & 2.88 \\
\hline $\mathrm{Cu}-\mathrm{L} 3$ & {$\left[\mathrm{CuC}_{15} \mathrm{H}_{16} \mathrm{~N}_{4} \mathrm{O}_{4} \mathrm{Cl}_{2}\right]$} & $1: 1$ & 295 & $40.04 \quad(40.6)$ & $3.55(3.9)$ & $12.45(12.8)$ & $15.57(15.2)$ & $14.12(14.3)$ & 1.99 \\
\hline $\mathrm{Cu}-(\mathrm{L} 3) 2$ & {$\left[\mathrm{CuC}_{30} \mathrm{H}_{28} \mathrm{~N}_{8} \mathrm{O}_{7}\right]$} & $1: 2$ & 306 & $53.29(53.4)$ & $4.14(4.3)$ & $16.5816 .7)$ & -- & $9.40(9.7)$ & 1.84 \\
\hline Zn-L3 & {$\left[\mathrm{ZnC}_{15} \mathrm{H}_{16} \mathrm{~N}_{4} \mathrm{O}_{4} \mathrm{Cl}_{2}\right]$} & $1: 1$ & 338 & $39.87(40.3)$ & $3.54(3.6)$ & $12.40(11.9)$ & $15.50(15.3)$ & $14.48(15.0)$ & -- \\
\hline Zn-(L3)2 & {$\left[\mathrm{ZnC}_{30} \mathrm{H}_{30} \mathrm{~N}_{8} \mathrm{O}_{8}\right]$} & $1: 2$ & 357 & $51.76(51.6)$ & $4.31(4.2)$ & $16.10(16.4)$ & -- & $9.40(9.5)$ & -- \\
\hline
\end{tabular}


Table 2. IR band assignments for the investigated ligands (L1-L3).

\begin{tabular}{cccc}
\hline L1 & L2 & L3 & Band assignment \\
\hline-- & -- & $3210 \mathrm{~m}$ & $v \mathrm{NH}$ \\
$3050 \mathrm{~m}$ & $3048 \mathrm{~m}$ & $3070 \mathrm{~m}$ & $v \mathrm{CH}$ \\
$1705 \mathrm{w}$ & $1678 \mathrm{w}$ & $1688 \mathrm{w}$ & $v \mathrm{C}=\mathrm{O}$ \\
$1652 \mathrm{~m}$ & $1595 \mathrm{~m}$ & $1629 \mathrm{~m}$ & $v \mathrm{C}=\mathrm{N}$ \\
$1499 \mathrm{~m}$ & $1493 \mathrm{~m}$ & $1494 \mathrm{~m}$ & $v \mathrm{C}=\mathrm{C}$ \\
$1410 \mathrm{~s}$ & $1414 \mathrm{~s}$ & $1395 \mathrm{~s}$ & $v \mathrm{~N}=\mathrm{O}$ \\
\hline
\end{tabular}

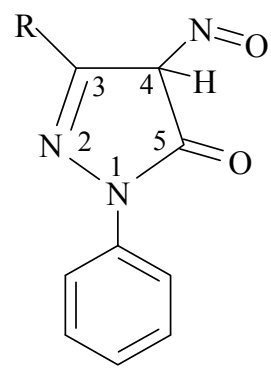

For ligand L1, a singlet observed at $2.40 \mathrm{ppm}$ is assigned to $\mathrm{CH}_{3}$ protons (the integration curve shows three protons). The signals observed at 7.23-7.84, 7.20-8.17 and 7.03-7.87 ppm are assigned to the aromatic hydrogen protons (the integration curve shows five and ten protons for the investigated ligands L1-L3, respectively). The spectrum of ligand L3 exhibits a singlet signal observed at $6.43 \mathrm{ppm}$ is assigned to NH proton (the integration curve shows one proton).

\subsubsection{Electronic Spectral Studies}

The electronic spectral band of the investigated ligands scanned in different organic solvents are depicted in Table 3. In methanol solution, ligands L1 and L2 show three bands, the first one at 253-268 nm referred to $\pi-\pi^{*}$ transition within the phenyl rings. The second band observed at $317-321 \mathrm{~nm}$ is ascribed to $\mathrm{n}-\pi^{*}$ transition of the carbonyl group. The third band at $385-400 \mathrm{~nm}$ arises from a transition involving electron migration along the entire conjugate system of the ligand i.e. comprises charge transfer (CT) from phenyl ring to the carbonyl group by resonance and from hetero ring by induction [17]. In case of chloroform, cyclohexane, isopropanol and dioxane, the spectra show two bands within the range $260-423 \mathrm{~nm}$. The first band at $260-263 \mathrm{~nm}$ is assigned to $\pi-\pi^{*}$ transition within the phenyl rings. The second band at $403-423 \mathrm{~nm}$ is ascribed to charge transfer interaction from the phenyl ring to the carbonyl group. For ligand L3 only one absorption band observed at 248-259 $\mathrm{nm}$ which may be ascribed to the high energy $\pi-\pi^{*}$ transition within the phenyl rings.

The ionization potential (Ip) of the investigated ligands (L1-L3) is calculated from their electronic spectral data applying the relationships previously applied [18-20]. The value of the experimental transition energies $\left(\mathrm{E}_{\mathrm{CT}}\right)$ and oscillator strengths (f) were calculated from $\lambda_{\max }$ of the electronic spectra applying the equations previously reported [18-20].

The calculated $\mathrm{E}_{\mathrm{CT}}$ values, as well as, the corresponding ionization potential (Ip) of the investigated ligands L1-L3 in different organic solvents are listed in Table 3. The variation in Ip values was found to follow the same order as $\lambda_{\max }$ of the CT band.

\subsection{Characterization of the Complexes}

The solid complexes were subjected to elemental analysis and metal content, infrared (FT-IR), ultraviolet and visible spectra (UV-Vis.), magnetic susceptibility $\left(\mu_{\text {eff. }}\right)$ and thermal analysis. The results of elemental analysis are given in Table 1 and are in good agreement with those calculated by the proposed formulae for $1: 1$ and 1:2 (M:L) solid complexes.

\subsubsection{Conductimetric Measurements}

Conductimetric titrations of $\mathrm{Mn}^{2+}, \mathrm{Co}^{2+}, \mathrm{Ni}^{2+}, \mathrm{Cu}^{2+}$ and $\mathrm{Zn}^{2+}$ metal ions with the investigated nitrosopyrazolone derivatives (L1-L3) were obtained by plotting the calculated molar ratio $[\mathrm{L}] /[\mathrm{M}]$ against the corrected molar conductance values. The results indicate that the conductance increases with the addition of the metal ion solution due to the release of the highly conducting hydrogen ions which may be present in nitroso-oxime tautomers as a result of chelation $[10,16]$. The titration curves show the presence of two distinctive breaks at metal to ligand 1:1 and 1:2 (M:L), respectively.

The prepared solid complexes of $\mathrm{Mn}^{2+}, \mathrm{Co}^{2+}, \mathrm{Ni}^{2+}$, $\mathrm{Cu}^{2+}$ and $\mathrm{Zn}^{2+}$ metal ions with the investigated ligands (L1-L3) were subjected to elemental analysis for their C, $\mathrm{H}, \mathrm{N}, \mathrm{Cl}$ and metal content [21], infrared (FT-IR), ultraviolet and visible spectra (UV-Vis.), magnetic susceptibility $\left(\mu_{\text {eff. }}\right)$ and thermal analysis.

\subsubsection{Infrared Studies}

Infrared spectral data of the investigated complexes display interesting changes which may give a reasonable idea about these complexes. However, if these changes were interpreted in relation to elemental analysis in Table 1 , also the thermogravimetric analysis, molar conductance, electronic spectra and magnetic susceptibility measurements, the structure of the solid complexes may be clarified.

In the spectra of the complexes (Table 4) the band observed within the range 1410-1395 $\mathrm{cm}^{-1}$ [14] assigned to $v \mathrm{~N}=\mathrm{O}$ in the free ligands shiftes to lower wave num- 
Table 3. The transition energy $\left(\mathrm{E}_{\mathrm{CT}}\right)$, ionization potential $\left(\mathrm{I}_{\mathrm{P}}\right)$, oscillator strengths $(f)$ and molar absorptivity $(\varepsilon)$ derived from the electronic spectra of ligands L1 and L2 in different organic solvents.

\begin{tabular}{|c|c|c|c|c|c|c|c|}
\hline Ligand & Solvent & Absorbance & $\lambda_{\max , \mathrm{nm}}$ & $\mathrm{E}_{\mathrm{CT}}$ & $\mathrm{I}_{\mathrm{P}}$ & $f$ & $\varepsilon_{\max } \times 10^{-4}$ \\
\hline \multirow{5}{*}{$\mathrm{L} 1$} & Chloroform & 0.06 & 403 & 3.07 & 7.30 & 0.02 & 0.12 \\
\hline & Cyclohexane & 0.06 & 403 & 3.07 & 7.30 & 0.02 & 0.13 \\
\hline & Isopropanol & 0.08 & 403 & 3.07 & 7.23 & 0.03 & 0.16 \\
\hline & Dioxane & 0.06 & 414 & 2.99 & 7.21 & 0.02 & 0.12 \\
\hline & Methanol & 0.12 & 385 & 3.22 & 7.39 & 0.04 & 0.24 \\
\hline \multirow{4}{*}{ L2 } & Chloroform & 0.07 & 423 & 2.93 & 7.16 & 0.06 & 0.28 \\
\hline & Isopropanol & 0.30 & 326 & 3.80 & 7.84 & 0.12 & 1.20 \\
\hline & Dioxane & 0.07 & 411 & 3.01 & 7.23 & 0.05 & 0.28 \\
\hline & Methanol & 0.10 & 400 & 3.09 & 7.29 & 0.06 & 0.40 \\
\hline
\end{tabular}

ber indicating the involvement of the $\mathrm{N}=\mathrm{O}$ group in chelation. Also, the shift of $\mathrm{N}=\mathrm{O}$ group indicated that it is a center of chelation as it loses its double bond character. The band observed within the range 1705-1678 $\mathrm{cm}^{-1}$ assigned to $\mathrm{vC}=\mathrm{O}$ in the free ligands shiftes to lower wave number $\left(1610-1650 \mathrm{~cm}^{-1}\right)$ indicating the involvement of the $\mathrm{C}=\mathrm{O}$ group in chelation as it also loses its double bond character [14]. The $\mathrm{OH}$ stretching frequency appears within the range $3336-3447 \mathrm{~cm}^{-1}$ for 1:1 and 1:2 complexes as broad band. This is due to the presence of water of hydration and/or coordinated water molecules. In some complexes, a sharp band appears within the range $3423-3640 \mathrm{~cm}^{-1}$ ascribed to chelated $\mathrm{OH}^{-}$, which replace the $\mathrm{Cl}^{-}$ion in coordination sphere. The $\mathrm{OH}$ frequency will be masked under the previously detected broad band [16]. The spectra of the metal complexes exhibit bands in the range $478-550 \mathrm{~cm}^{-1}$ that may be assigned to $v \mathrm{M}-\mathrm{O}$ stretching frequency $[22,23]$. These bands are not observed in the spectra of the free ligands and are possibly due to the formation of coordinated bond $(\mathrm{M} \leftarrow \mathrm{O})$ or $(\mathrm{M}-\mathrm{O})$.

\subsubsection{Thermal Analysis}

TG analyses are very useful method for investigating the thermal decomposition of solid substances involving simple metal salts [24], as well as for complex compounds $[25,26]$. The thermogram follows the decrease in sample weight with the linear increase in heat treatment temperature $\left(10^{\circ} \mathrm{C} \min ^{-1}\right)$ up to $800^{\circ} \mathrm{C}$. The aim of the thermal analysis is to obtain information concerning the thermal stability of the investigated complexes as seen in

Table 5 and Figure 1, to decide whether water molecules are inside or outside the coordination sphere.

For Mn-L3 (1:1) complex, a mass loss occurred within the temperature range $34-106^{\circ} \mathrm{C}$ corresponding to the loss of $3.25 \%$ (Calcd $3.27 \%$ ) for one molecule of water
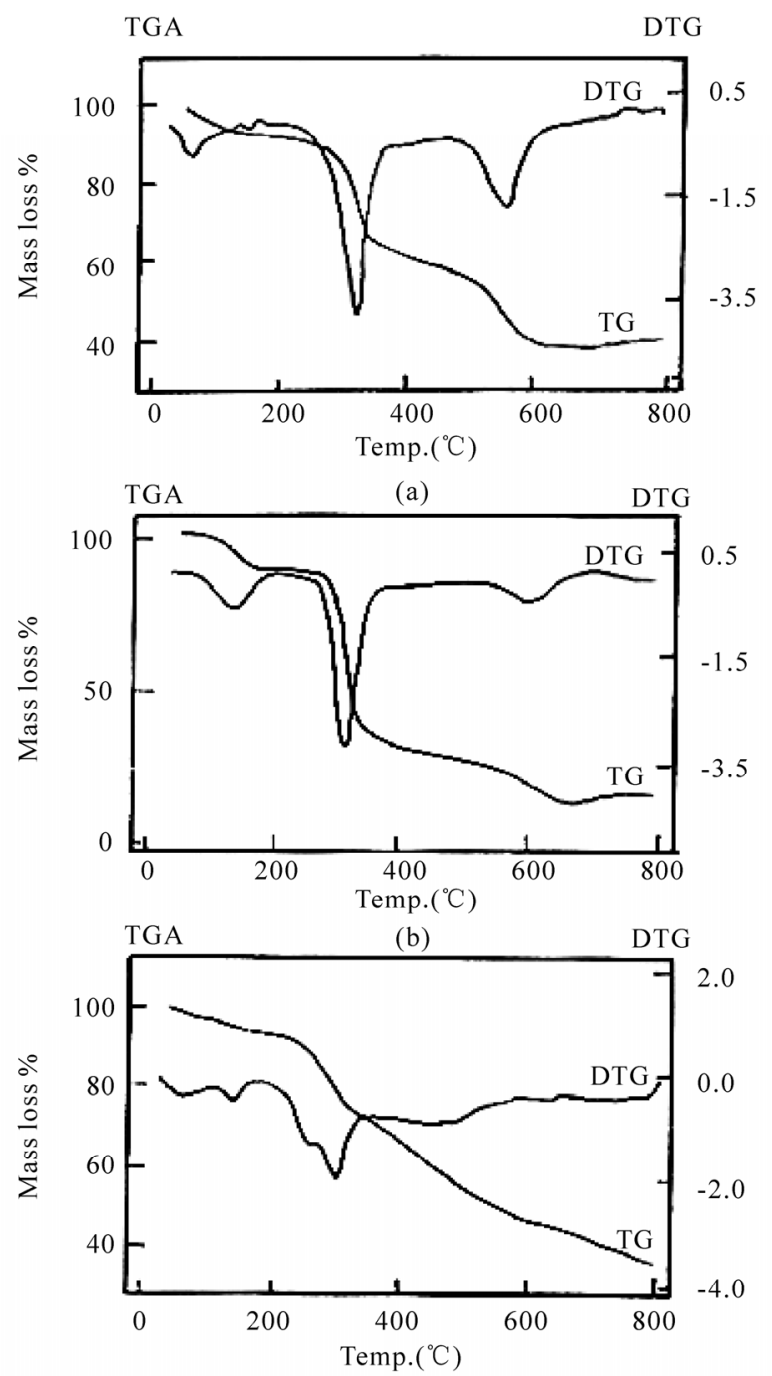

(c)

Figure 1. Thermogravimetric and derivative thermal analyses curves of Ni-L1 (a), Co-L2 (b) and Mn-L3 (c) 1:1 complex. 
Table 4. IR band assignment of $\mathrm{Mn}^{2+}, \mathrm{Co}^{2+}, \mathrm{Ni}^{2+}, \mathrm{Cu}^{2+}$ and $\mathrm{Zn}^{2+}$ complexes with the investigated ligands (L1-L3).

\begin{tabular}{|c|c|c|c|c|c|c|c|c|}
\hline Complex & M:L & $v\left(\mathrm{OH}^{-}\right)$ & $v(\mathrm{OH})\left(\mathrm{H}_{2} \mathrm{O}\right)$ & $v(\mathrm{NH})$ & $v(\mathrm{C}=\mathrm{O})$ & $v(\mathrm{C}=\mathrm{N})$ & $v(\mathrm{~N}=\mathrm{O})$ & $v(\mathrm{M}-\mathrm{O})$ \\
\hline$\left[\mathrm{Mn}(\mathrm{L} 1)(\mathrm{Cl})_{2}\left(\mathrm{H}_{2} \mathrm{O}\right)_{2}\right] \cdot 4 \mathrm{H}_{2} \mathrm{O}$ & $1: 1$ & -- & $3430 \mathrm{~s}$ & -- & $1636 \mathrm{w}$ & $1593 \mathrm{~m}$ & $1335 \mathrm{~s}$ & $500 \mathrm{~m}$ \\
\hline$\left[\mathrm{Mn}(\mathrm{L} 1)_{2}(\mathrm{OH})_{2}\right]$ & $1: 2$ & $3465 \mathrm{~s}$ & $3435 \mathrm{~s}$ & -- & $1637 \mathrm{w}$ & $1523 \mathrm{~m}$ & $1340 \mathrm{~s}$ & $508 \mathrm{~m}$ \\
\hline$\left[\mathrm{Co}(\mathrm{L} 1)(\mathrm{Cl})_{2}\left(\mathrm{H}_{2} \mathrm{O}\right)_{2}\right] \cdot \mathrm{H}_{2} \mathrm{O}$ & $1: 1$ & -- & $3400 \mathrm{~s}$ & -- & $1630 \mathrm{w}$ & -- & $1350 \mathrm{~s}$ & $505 \mathrm{~m}$ \\
\hline$\left[\mathrm{Co}(\mathrm{L} 1)_{2}(\mathrm{OH})_{2}\right] \cdot 2 \mathrm{H}_{2} \mathrm{O}$ & $1: 2$ & $3552 \mathrm{~s}$ & $3398 \mathrm{~s}$ & -- & $1635 \mathrm{w}$ & $1499 \mathrm{w}$ & $1340 \mathrm{~s}$ & $509 \mathrm{~m}$ \\
\hline$\left[\mathrm{Ni}(\mathrm{L} 1)(\mathrm{Cl})_{2}\left(\mathrm{H}_{2} \mathrm{O}\right)_{2}\right] .8 \mathrm{H}_{2} \mathrm{O}$ & $1: 1$ & -- & $3425 \mathrm{~s}$ & -- & $1631 \mathrm{w}$ & -- & $1353 \mathrm{~s}$ & $550 \mathrm{~m}$ \\
\hline$\left[\mathrm{Ni}(\mathrm{L} 1)_{2}(\mathrm{OH})_{2}\right] \cdot \mathrm{H}_{2} \mathrm{O}$ & $1: 2$ & $3463 \mathrm{~s}$ & $3418 \mathrm{~s}$ & -- & $1631 \mathrm{w}$ & -- & $1340 \mathrm{~s}$ & $510 \mathrm{~m}$ \\
\hline$\left[\mathrm{Cu}(\mathrm{Ll})(\mathrm{Cl})_{2}\left(\mathrm{H}_{2} \mathrm{O}\right)_{2}\right] \cdot 2 \mathrm{H}_{2} \mathrm{O}$ & $1: 1$ & -- & $3352 \mathrm{~s}$ & -- & $1623 \mathrm{w}$ & $1488 \mathrm{w}$ & $1375 \mathrm{~s}$ & $530 \mathrm{~m}$ \\
\hline$\left[\mathrm{Cu}(\mathrm{L} 1)_{2}(\mathrm{OH})_{2}\right] \cdot 3 \mathrm{H}_{2} \mathrm{O}$ & $1: 2$ & $3435 \mathrm{~s}$ & $3358 \mathrm{~s}$ & -- & $1646 \mathrm{w}$ & -- & $1408 \mathrm{~s}$ & $509 \mathrm{~m}$ \\
\hline$\left[\mathrm{Zn}(\mathrm{L} 1)(\mathrm{Cl})_{2}\left(\mathrm{H}_{2} \mathrm{O}\right)_{2}\right] \cdot \mathrm{H}_{2} \mathrm{O}$ & $1: 1$ & -- & $3362 \mathrm{~s}$ & -- & $1637 \mathrm{w}$ & $1527 \mathrm{~m}$ & $1365 \mathrm{~s}$ & $509 \mathrm{~m}$ \\
\hline$\left[\mathrm{Zn}(\mathrm{L} 1)_{2}(\mathrm{OH})_{2}\right] \cdot \mathrm{H}_{2} \mathrm{O}$ & $1: 2$ & $3444 \mathrm{~s}$ & $3396 \mathrm{~s}$ & -- & $1637 w$ & $1535 \mathrm{~m}$ & $1340 \mathrm{~s}$ & $510 \mathrm{~m}$ \\
\hline$\left[\mathrm{Mn}(\mathrm{L} 2)(\mathrm{Cl})_{2}\left(\mathrm{H}_{2} \mathrm{O}\right)_{2}\right] \cdot 2 \mathrm{H}_{2} \mathrm{O}$ & $1: 1$ & -- & $3360 \mathrm{~s}$ & -- & $1632 \mathrm{w}$ & $1580 \mathrm{~m}$ & $1356 \mathrm{~s}$ & $509 \mathrm{~m}$ \\
\hline$\left[\mathrm{Mn}(\mathrm{L} 2)_{2}(\mathrm{OH})_{2}\right] \cdot 2 \mathrm{H}_{2} \mathrm{O}$ & $1: 2$ & $3500 \mathrm{~s}$ & $3397 \mathrm{~s}$ & -- & $1632 \mathrm{w}$ & $1595 \mathrm{~m}$ & $1356 \mathrm{~s}$ & $500 \mathrm{~m}$ \\
\hline$\left[\mathrm{Co}(\mathrm{L} 2)(\mathrm{Cl})_{2}\left(\mathrm{H}_{2} \mathrm{O}\right)_{2}\right] \cdot \mathrm{H}_{2} \mathrm{O}$ & $1: 1$ & -- & $3405 \mathrm{~s}$ & -- & $1627 \mathrm{~m}$ & $1595 \mathrm{~m}$ & $1358 \mathrm{~s}$ & $488 \mathrm{~m}$ \\
\hline$\left[\mathrm{Co}(\mathrm{L} 2)_{2}(\mathrm{OH})_{2}\right] \cdot 2 \mathrm{H}_{2} \mathrm{O}$ & $1: 2$ & $3630 \mathrm{~s}$ & $3360 \mathrm{~s}$ & -- & $1627 \mathrm{~m}$ & $1595 \mathrm{w}$ & $1357 \mathrm{~s}$ & $500 \mathrm{~m}$ \\
\hline$\left[\mathrm{Ni}(\mathrm{L} 2)(\mathrm{Cl})_{2}\left(\mathrm{H}_{2} \mathrm{O}\right)_{2}\right] \cdot \mathrm{H}_{2} \mathrm{O}$ & $1: 1$ & -- & $3433 \mathrm{~s}$ & -- & $1632 \mathrm{w}$ & $1596 \mathrm{w}$ & $1359 \mathrm{~s}$ & $478 \mathrm{w}$ \\
\hline$\left[\mathrm{Ni}(\mathrm{L} 2)_{2}(\mathrm{OH})_{2}\right] \cdot 2 \mathrm{H}_{2} \mathrm{O}$ & $1: 2$ & $3640 \mathrm{~s}$ & $3405 \mathrm{~s}$ & -- & $1632 \mathrm{w}$ & $1596 \mathrm{w}$ & $1359 \mathrm{~s}$ & $487 \mathrm{w}$ \\
\hline$\left[\mathrm{Cu}(\mathrm{L} 2)(\mathrm{Cl})_{2}\left(\mathrm{H}_{2} \mathrm{O}\right)_{2}\right] \cdot \mathrm{H}_{2} \mathrm{O}$ & $1: 1$ & -- & $3369 \mathrm{~s}$ & -- & $1620 \mathrm{w}$ & $1532 \mathrm{~m}$ & $1421 \mathrm{~s}$ & $486 \mathrm{~m}$ \\
\hline$\left[\mathrm{Cu}(\mathrm{L} 2)_{2}(\mathrm{OH})_{2}\right] \cdot \mathrm{H}_{2} \mathrm{O}$ & $1: 2$ & $3610 \mathrm{~s}$ & $3289 \mathrm{~s}$ & -- & $1624 \mathrm{w}$ & $1610 \mathrm{~m}$ & $1419 \mathrm{~s}$ & $486 \mathrm{~m}$ \\
\hline$\left[\mathrm{Zn}(\mathrm{L} 2)(\mathrm{Cl})_{2}\left(\mathrm{H}_{2} \mathrm{O}\right)_{2}\right] \cdot \mathrm{H}_{2} \mathrm{O}$ & $1: 1$ & -- & $3402 \mathrm{~s}$ & -- & $1635 \mathrm{~m}$ & $1612 \mathrm{~m}$ & $1378 \mathrm{~s}$ & $507 \mathrm{w}$ \\
\hline$\left[\mathrm{Zn}(\mathrm{L} 2)_{2}(\mathrm{OH})_{2}\right] \cdot 2 \mathrm{H}_{2} \mathrm{O}$ & $1: 2$ & $3630 \mathrm{~s}$ & $3388 \mathrm{~s}$ & -- & $1615 \mathrm{~m}$ & $1614 \mathrm{~m}$ & $1380 \mathrm{~s}$ & $497 w$ \\
\hline$\left[\mathrm{Mn}(\mathrm{L} 3)(\mathrm{Cl})_{2}\left(\mathrm{H}_{2} \mathrm{O}\right)_{2}\right] \cdot 6 \mathrm{H}_{2} \mathrm{O}$ & $1: 1$ & -- & $3445 \mathrm{~s}$ & $3350 \mathrm{~m}$ & $1619 w$ & $1570 \mathrm{~m}$ & $1377 \mathrm{~s}$ & $505 \mathrm{w}$ \\
\hline$\left[\mathrm{Mn}(\mathrm{L} 3)_{2}(\mathrm{OH})_{2}\right] \cdot 2 \mathrm{H}_{2} \mathrm{O}$ & $1: 2$ & $3423 \mathrm{~s}$ & $3340 \mathrm{~s}$ & $3220 \mathrm{~m}$ & $1650 \mathrm{w}$ & $1631 \mathrm{~m}$ & $1361 \mathrm{~s}$ & $504 \mathrm{w}$ \\
\hline$\left[\mathrm{Co}(\mathrm{L} 3)(\mathrm{Cl})_{2}\left(\mathrm{H}_{2} \mathrm{O}\right)_{2}\right] \cdot 2 \mathrm{H}_{2} \mathrm{O}$ & $1: 1$ & -- & $3447 \mathrm{~s}$ & $3335 \mathrm{~m}$ & $1620 \mathrm{w}$ & $1575 \mathrm{w}$ & $1378 \mathrm{~s}$ & $510 \mathrm{w}$ \\
\hline$\left[\mathrm{Co}(\mathrm{L} 3)_{2}(\mathrm{Cl})_{2}\right] . \mathrm{H}_{2} \mathrm{O}$ & $1: 2$ & -- & $3336 \mathrm{~s}$ & $3210 \mathrm{~m}$ & $1627 \mathrm{w}$ & $1570 \mathrm{w}$ & $1362 \mathrm{~s}$ & $508 \mathrm{w}$ \\
\hline$\left[\mathrm{Ni}(\mathrm{L} 3)(\mathrm{Cl})_{2}\right] .2 \mathrm{H}_{2} \mathrm{O}$ & $1: 1$ & -- & $3344 \mathrm{~s}$ & $3200 \mathrm{~m}$ & $1621 \mathrm{w}$ & $1600 \mathrm{~m}$ & $1390 \mathrm{~s}$ & $510 \mathrm{~m}$ \\
\hline$\left[\mathrm{Ni}(\mathrm{L} 3)_{2}(\mathrm{Cl})_{2}\right] \cdot 6 \mathrm{H}_{2} \mathrm{O}$ & $1: 2$ & -- & $3344 \mathrm{~s}$ & $3200 \mathrm{~m}$ & $1621 \mathrm{w}$ & $1563 \mathrm{~m}$ & $1390 \mathrm{~s}$ & $510 \mathrm{~m}$ \\
\hline$\left[\mathrm{Cu}(\mathrm{L} 3)(\mathrm{Cl})_{2}\right] \cdot 2 \mathrm{H}_{2} \mathrm{O}$ & $1: 1$ & -- & $3348 \mathrm{~s}$ & $3220 \mathrm{~m}$ & $1610 \mathrm{w}$ & $1580 \mathrm{~m}$ & $1365 \mathrm{~s}$ & $510 \mathrm{~m}$ \\
\hline$\left[\mathrm{Cu}(\mathrm{L} 3)_{2}(\mathrm{OH})_{2}\right] \cdot \mathrm{H}_{2} \mathrm{O}$ & $1: 2$ & $3446 \mathrm{~s}$ & $3348 \mathrm{~s}$ & $3230 \mathrm{~m}$ & $1612 \mathrm{w}$ & $1550 \mathrm{~m}$ & $1360 \mathrm{~s}$ & $511 \mathrm{~m}$ \\
\hline$\left[\mathrm{Zn}(\mathrm{L} 3)(\mathrm{Cl})_{2}\left(\mathrm{H}_{2} \mathrm{O}\right)_{2}\right]$ & $1: 1$ & -- & $3354 \mathrm{~s}$ & $3227 \mathrm{~m}$ & $1624 \mathrm{w}$ & $1567 \mathrm{w}$ & $1394 \mathrm{~s}$ & $494 \mathrm{w}$ \\
\hline$\left[\mathrm{Zn}(\mathrm{L} 3)_{2}(\mathrm{OH})_{2}\right] \cdot 2 \mathrm{H}_{2} \mathrm{O}$ & $1: 2$ & $3552 \mathrm{~s}$ & $3364 \mathrm{~s}$ & $3245 \mathrm{~m}$ & $1618 \mathrm{w}$ & $1615 \mathrm{w}$ & $1401 \mathrm{~s}$ & $497 w$ \\
\hline
\end{tabular}

s: strong, m: medium, w: weak

and at the temperature range $108-170^{\circ} \mathrm{C}$ another loss of $2.88 \%$ (Calcd. $3.20 \%$ ) for another one water molecule. In the temperature range $170-256^{\circ} \mathrm{C}$ a mass loss of $14.44 \%$ (Calcd. 14.03\%) corresponding to four water molecules. At the temperature $256-351^{\circ} \mathrm{C}$ a loss of $8.10 \%$ (Calcd. $8.16 \%$ ) for two coordinated water molecules. At higher temperature range $353-585^{\circ} \mathrm{C}$ a loss of $23.40 \%$ (Calcd. 23.78 ) and at the temperature range $585-797^{\circ} \mathrm{C}$ a loss of $11.68 \%$ (Calcd. 11.88\%) corresponding to a loss of the organic moiety as an intermediate species. At the end of the thermogram at higher temperature the metal oxide and chloride residues $\mathrm{MnO}$ and $\mathrm{MnCl}_{2}$ are formed as final 
Table 5. Thermogravimetric results of $\mathrm{Mn}^{2+}, \mathrm{Co}^{2+}$ and $\mathrm{Ni}^{2+}$ complexes with the investigated ligands (L1-L3).

\begin{tabular}{|c|c|c|c|c|c|}
\hline & & & Calcd. & Found & Assignment \\
\hline Complex & M. Wt. & Temp. ${ }^{\circ} \mathrm{C}$ & loss $\%$ & loss $\%$ & \\
\hline$\left[\mathrm{Mn}\left(\mathrm{C}_{15} \mathrm{H}_{12} \mathrm{~N}_{4} \mathrm{O}_{2}\right)(\mathrm{Cl})_{2}\left(\mathrm{H}_{2} \mathrm{O}\right)_{2}\right] \cdot 6 \mathrm{H}_{2} \mathrm{O}$ & 548.9 & $34-105$ & 3.27 & 3.25 & $\mathrm{H}_{2} \mathrm{O}$ \\
\hline$\left[\mathrm{Mn}\left(\mathrm{C}_{15} \mathrm{H}_{12} \mathrm{~N}_{4} \mathrm{O}_{2}\right)(\mathrm{Cl})_{2}\left(\mathrm{H}_{2} \mathrm{O}\right)_{2}\right] \cdot 5 \mathrm{H}_{2} \mathrm{O}$ & 530.9 & $105-170$ & 3.39 & 2.88 & $\mathrm{H}_{2} \mathrm{O}$ \\
\hline$\left[\mathrm{Mn}\left(\mathrm{C}_{15} \mathrm{H}_{12} \mathrm{~N}_{4} \mathrm{O}_{2}\right)(\mathrm{Cl})_{2}\left(\mathrm{H}_{2} \mathrm{O}\right)_{2}\right] \cdot 4 \mathrm{H}_{2} \mathrm{O}$ & 512.9 & $170-256$ & 14.03 & 14.44 & $4 \mathrm{H}_{2} \mathrm{O}$ \\
\hline$\left[\mathrm{Mn}\left(\mathrm{C}_{15} \mathrm{H}_{12} \mathrm{~N}_{4} \mathrm{O}_{2}\right)(\mathrm{Cl})_{2}\left(\mathrm{H}_{2} \mathrm{O}\right)_{2}\right]$ & 440.9 & $256-351$ & 8.16 & 8.10 & 2 coordinated $\mathrm{H}_{2} \mathrm{O}$ \\
\hline$\left[\mathrm{Mn}\left(\mathrm{C}_{15} \mathrm{H}_{12} \mathrm{~N}_{4} \mathrm{O}_{2}\right)(\mathrm{Cl})_{2}\right]$ & 404.9 & $353-585$ & 23.78 & 23.40 & -NHPh, NO \\
\hline \multirow[t]{2}{*}[\mathrm{Mn}(\mathrm{C}_{12}\mathrm{H}_{6}\mathrm{O})(\mathrm{Cl})_{2}]{} & 282.9 & $585-797$ & 11.88 & 11.68 & $3 \mathrm{C}, \mathrm{H}, \mathrm{N}_{2}$ \\
\hline & & 800 & 35.66 & 35.71 & $\mathrm{MnCl}_{2}+\mathrm{MnO}$ \\
\hline$\left[\mathrm{Co}\left(\mathrm{C}_{15} \mathrm{H}_{11} \mathrm{~N}_{3} \mathrm{O}_{2}\right)(\mathrm{Cl})_{2}\left(\mathrm{H}_{2} \mathrm{O}\right)_{2}\right] . \mathrm{H}_{2} \mathrm{O}$ & 447.9 & $79-213$ & 12.05 & 11.90 & $\mathrm{H}_{2} \mathrm{O}, 2$ coordinated $\mathrm{H}_{2} \mathrm{O}$ \\
\hline$\left[\mathrm{Co}\left(\mathrm{C}_{15} \mathrm{H}_{11} \mathrm{~N}_{3} \mathrm{O}_{2}\right)(\mathrm{Cl})_{2}\right]$ & 393.9 & $213-460$ & 61.84 & 61.00 & $2 \mathrm{Ph}, \mathrm{Cl}_{2}, \mathrm{C}-\mathrm{CH}, \mathrm{CO}$ \\
\hline \multirow[t]{2}{*}[\mathrm{Co}(\mathrm{N}_{3}\mathrm{O})]{} & 116.9 & $461-721$ & 12.94 & 13.00 & $\mathrm{NO}, \mathrm{N}_{2}$ \\
\hline & & $721-800$ & 16.72 & 16.50 & $\mathrm{CoO}$ \\
\hline$\left[\mathrm{Ni}\left(\mathrm{C}_{10} \mathrm{H}_{9} \mathrm{~N}_{3} \mathrm{O}_{2}\right)(\mathrm{Cl})_{2}\left(\mathrm{H}_{2} \mathrm{O}\right)_{2}\right] \cdot 8 \mathrm{H}_{2} \mathrm{O}$ & 511.7 & $37-144$ & 7.03 & 6.50 & $2 \mathrm{H}_{2} \mathrm{O}$ \\
\hline$\left[\mathrm{Ni}\left(\mathrm{C}_{10} \mathrm{H}_{9} \mathrm{~N}_{3} \mathrm{O}_{2}\right)(\mathrm{Cl})_{2}\left(\mathrm{H}_{2} \mathrm{O}\right)_{2}\right] \cdot 6 \mathrm{H}_{2} \mathrm{O}$ & 475.7 & $146-370$ & 28.14 & 28.90 & $6 \mathrm{H}_{2} \mathrm{O}, 2$ coordinated $\mathrm{H}_{2} \mathrm{O}$ \\
\hline \multirow[t]{2}{*}[\mathrm{Ni}(\mathrm{C}_{10}\mathrm{H}_{9}\mathrm{N}_{3}\mathrm{O}_{2})(\mathrm{Cl})_{2}]{} & 331.7 & $372-607$ & 24.62 & 24.60 & $\mathrm{~N}_{2}, \mathrm{C}-\mathrm{CH}, \mathrm{NO}, \mathrm{CH}_{3}, \mathrm{CO}$ \\
\hline & & $607-800$ & 39.71 & 39.99 & $\mathrm{NiCl}_{2}+\mathrm{NiO}$ \\
\hline
\end{tabular}

product, the remainder is $35.71 \%$ (Calcd. $35.66 \%$ ).

For Ni-L1 (1:1) complex, a mass loss occurred within the temperature range $36-144^{\circ} \mathrm{C}$ corresponding to the loss of $6.5 \%$ (Calcd. $7.03 \%$ ) for two hydrated water molecules and at the temperature range $146-370^{\circ} \mathrm{C}$ corresponding to a loss of $28.90 \%$ (Calcd. $28.14 \%$ ) for hydrated and two coordinated water molecules. In the temperature range $372-607^{\circ} \mathrm{C}$ a mass loss of $24.60 \%$ (Calcd. 24.62\%) corresponding to the formation of intermediate species through the decomposition of the organic moiety of the complex [15] and this continues till a constant weight is obtained where a mixture of nickel chloride and nickel oxide residue are formed, the remainder is $39.99 \%$ (Calcd. $39.71 \%$ ).

For Co-L2 (1:1) complex, a mass loss occurred within the temperature range $79-213^{\circ} \mathrm{C}$ corresponding to a loss of $11.90 \%$ (Calcd. $12.05 \%$ ) for three water molecules. At the temperature range $213-460{ }^{\circ} \mathrm{C}$ a loss of $61.00 \%$ (Calcd. 61.84\%) and at the temperature range $461-721^{\circ} \mathrm{C}$ a loss of $13.00 \%$ (Calcd. 12.94\%) corresponding to the formation of intermediate species. At higher temperature more than $721{ }^{\circ} \mathrm{C}$ and at the end of the process a metallic oxide residue $\mathrm{CoO}$ is formed, the remainder is $16.50 \%$ (Calcd. 16.72\%).

\subsubsection{Molar Conductance Measurements}

The molar conductivities of $1 \mathrm{mM}$ in DMF $\left(10^{-3} \mathrm{M}\right)$ of some of the given complexes show that the investigated complexes are neutral in nature since the values obtained are $7.45-37.7 \mathrm{ohm}^{-1} \mathrm{~cm}^{2} \mathrm{~mol}^{-1}$. These values were small to account for ionic complexes of the investigated metal ions.

For Mn-L1 (1:2), Co-L1 (1:1), Ni-L1 (1:1) and (1:2), $\mathrm{Cu}-\mathrm{L} 1(1: 2)$ and $\mathrm{Zn}-\mathrm{L} 1(1: 2)$, the values were 20.30, $17.29,7.45,13.88,19.46$ and $17.20 \mathrm{ohm}^{-1} \mathrm{~cm}^{2} \mathrm{~mol}^{-1}$, respectively.

For Mn-L2 (1:2), Co-L2 (1:2), Ni-L2 (1:2) and Cu-L2 $(1: 2)$ the values were $16.74,10.25,13.85$ and 11.17 $\mathrm{ohm}^{-1} \mathrm{~cm}^{2} \mathrm{~mol}^{-1}$, respectively.

For Mn-L3 (1:1), Co-L3 (1:2), Ni-L3 (1:1) and (1:2), $\mathrm{Cu}-\mathrm{L} 3$ (1:1) and Zn-L3 (1:1), the values were 25.30, 37.70, 20.90, 24.30, 32.7 and $13.25 \mathrm{ohm}^{-1} \mathrm{~cm}^{2} \mathrm{~mol}^{-1}$, respectively. These low conductivity values may be ascribed to the coordination of chloride ions, if present, rather than the ionic association to the metal ions during complex formation. This directly supports the fact that all of the investigated complexes are non-ionic in nature.

\subsubsection{Electronic Spectral and Magnetic Studies} The $\mathrm{Mn}^{2+}, \mathrm{Co}^{2+}, \mathrm{Ni}^{2+}$ and $\mathrm{Cu}^{2+}$ complexes (Table 1) show a high spin value $\mathrm{d}^{5}, \mathrm{~d}^{3}, \mathrm{~d}^{2}$ and $\mathrm{d}^{1}$ configurations as the ground state, the magnetic susceptibility ( $\mu_{\text {eff. }}=$ 5.66-5.94 B. M.), $\left(\mu_{\text {eff. }}=3.78-3.98\right.$ B. M. $),\left(\mu_{\text {eff. }}=\right.$ 2.88-3.12 B. M.) and ( $\mu_{\text {eff. }}=1.84-2.10$ B. M.) with the ligands (L1-L3), respectively, indicating $\left(\mathrm{t}_{2 g}^{3} \mathrm{e}_{g}^{2}\right),\left(\mathrm{t}_{2 g}^{3} \mathrm{e}_{g}\right)$, $\left(\mathrm{t}_{2 g}^{2} \mathrm{e}_{g}\right)$ and $\left(\mathrm{t}_{2 g}^{1} \mathrm{e}_{g}\right)$. The high spin values of magnetic susceptibility may be due to the ligands being weak ligands [27]. 
Electronic absorption spectra of the free ligands and some of their chelates were recorded in DMF. In the free ligands the CT band appears in the range $385-400 \mathrm{~nm}$ for the ligands L1-L3. A shift to longer wavelength is observed on complex formation. This may be attributed to the $\mathrm{M} \rightarrow \mathrm{L}$ charge transfer $\mathrm{CT}$ spectra. A band of low intensity is observed at $460 \mathrm{~nm}$ for Co-L1 (1:1), and 458 $\mathrm{nm}$ for Co-L3 (1:2) which is typical for six-coordinate high-spin $\mathrm{Co}^{2+}$ complexes. The corresponding bands in the octahedral $\left[\mathrm{Co}\left(\mathrm{H}_{2} \mathrm{O}\right)_{6}\right]^{2+}$ ion have been assigned to ${ }^{4} \mathrm{~T}_{1 \mathrm{~g}} \rightarrow{ }^{4} \mathrm{~T}_{2 \mathrm{~g}}(\mathrm{~F}),{ }^{4} \mathrm{~T}_{1 \mathrm{~g}} \rightarrow{ }^{2} \mathrm{~A}_{1 \mathrm{~g}}(\mathrm{~F})$ and ${ }^{4} \mathrm{~T}_{1 \mathrm{~g}} \rightarrow{ }^{4} \mathrm{~T}_{1 \mathrm{~g}}(\mathrm{P})$ transitions, respectively [28]. The absorption spectral bands of $\mathrm{Ni}-\mathrm{L} 3(1: 1)$ at $458 \mathrm{~nm}$ and 450 for Ni-L2 (1:2) are assigned to the ${ }^{3} \mathrm{~A}_{2 \mathrm{~g}} \rightarrow{ }^{3} \mathrm{~T}_{1 \mathrm{~g}}(\mathrm{~F})$ and ${ }^{3} \mathrm{~A}_{2 \mathrm{~g}} \rightarrow{ }^{3} \mathrm{~T}_{1 \mathrm{~g}}$ (P) transitions, respectively, in an octahedral geometry [29] and is almost identical with that of the octahedral $\left[\mathrm{Ni}\left(\mathrm{H}_{2} \mathrm{O}\right)_{6}\right]^{2+}$ ion [30]. It is difficult to relate spectra with the structure of $\mathrm{Cu}^{2+}$ complexes, especially in view of the distorted geometry observed for its complexes [28].

Based on the above results the suggested structures of the 1:1 and 1:2 (M:L) complexes between the metal ions and the ligands can be represented as follows:

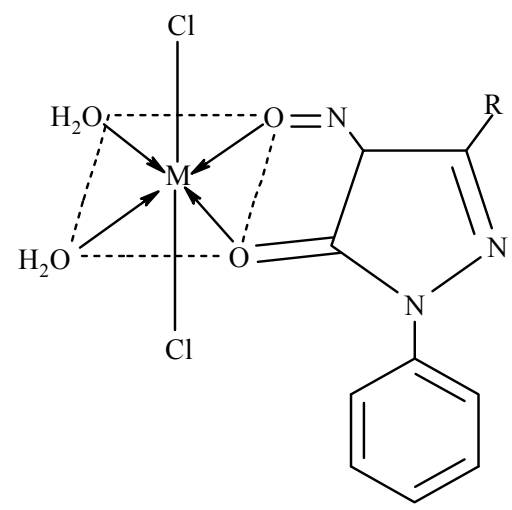

(1:1) complexes

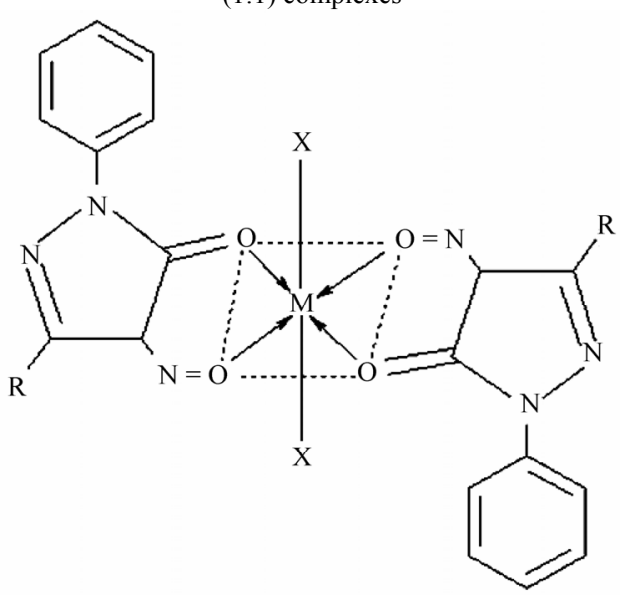

(1:2) complexes

$\mathrm{X}=\mathrm{OH}$ in all cases except for $\mathrm{Co}^{2+}$ and $\mathrm{Ni}^{2+}$ with ligand $\mathrm{L} 3$ $\mathrm{R}=\mathrm{CH}_{3^{-}}, \mathrm{Ph}-$ and $\mathrm{PhNH}-,(1: 2)$ complexes

\section{CONCLUSIONS}

In the present paper, the data obtained from elemental analysis, FT-IR, electronic absorption spectra, thermal analyses, molar conductivities and magnetic susceptibility measurements show that the complexes of $\mathrm{Mn}^{2+}$, $\mathrm{Co}^{2+}, \mathrm{Ni}^{2+}, \mathrm{Cu}^{2+}$ and $\mathrm{Zn}^{2+}$ metal ions with the investigated ligands L1-L3 may be formulated, where bonding in case of 1:1 and 1:2 complexes are formed through coordination with oxygen of the carbonyl group and nitroso group. The complexes obtained contain water of coordination in their sphere. The investigated ligands act as neutral bidentate ligands. The solid complexes prepared behave as non-electrolytes in DMF solution. The electronic spectra of the investigated ligands exhibits a CT band appears in the range $385-400 \mathrm{~nm}$ for the ligands L1-L3. A shift to higher wavelength is observed on complex formation which may be attributed to $\mathrm{M} \rightarrow \mathrm{L}$ charge transfer spectra. The bands observed at higher wavelengths which are not observed in the spectra of the free ligands may be ascribed to d-d electronic transition within the metal ions. The complexes exhibit an octahedral or distorted octahedral $\left(\mathrm{Cu}^{2+}\right.$ complexes) coordination with the investigated ligands.

\section{REFERENCES}

[1] Finar, I.L. (1973) Organic chemistry, the fundamental principle. 6th Edition, Longman, London, 846.

[2] Kuncheria, B. and Indrasenan, P. (1988) Thorium (IV) nitrate complexes with some substituted pyrazole-5- ones. Indian Journal of Chemistry, 27A(11), 1005- 1007.

[3] Enchev, V. and Neykov, G.D. (1992) Tautomerism of $\mathrm{N}$-unsubstituted pyrazolones (hydroxypyrazoles): MNDO and MNDO + CI study of C-substituted tautomers. Journal of Molecular Structure: Theochem, 258(3-4), 217-234.

[4] Nayak, A., Das, N.B., Mahapatra, B.B. and Mittra, A.S. (1981) Synthesis and fungitoxicity of cobalt(II) complexes with 2-pyrazolin-5-one derivatives. Journal of the Indian Chemical Society, 58(4), 347-349.

[5] Das, N.B., Nayak, A., Mahapatra, B.B. and Mittra, A.S. (1981) Complexes of $\mathrm{Co}(\mathrm{II}), \mathrm{Ni}(\mathrm{II}), \mathrm{Cu}(\mathrm{II})$ and $\mathrm{Zn}(\mathrm{II})$ with substituted pyrazolones used as potential fungicides. Journal of the Indian Chemical Society, 58(6), 337-339.

[6] Nayak, A. and Mittra, A.S. (1980) 4,4'-Bis-5-pyrazolones and their 4,4'-unsaturated products for possible use as fungicides. Journal of the Indian Chemical Society, 57(6), 643-645.

[7] Das, N.B. and Mittra, A.S. (1978) Heterocyclic fungicides. Part-III. Journal of the Indian Chemical Society, 55(8), 829-831.

[8] Singh, H., Srivastava, S. and Maheshwari, S. (1982) Thermal and other studies of copper and cobalt complexes of some ligands containing the N-O group. Thermochimica Acta, 57(3), 369-376.

[9] Lagercruntz, C. (1989) Acta Chemica Scandinavica, 43, 78. 
[10] Bartulin, J., Belmar, J., Gallardo, H. and Leon, G. (1994) Journal of Heterocyclic Chemistry, 31, 561.

[11] Enchev, V. and Angelova, S. (2009) Does tautomeric equilibrium exist in 4-nitroso-5-pyrazolones? Journal of Molecular Structure: Theochem, 897(1-3), 55-60.

[12] Vogel, A.I. (1989) A text book of practical organic chemistry. 5th Edition, Longman Scientific and Technical, London, 807.

[13] Weissberger, A. and Porter H.D. (1942) Investigation of pyrazole compounds. I, The reaction product of phenylhydrazine and ethyl cyanoacetate. Journal of the American Chemical Society, 64(9), 2133-2136.

[14] Abdel-Latif, S.A., El-Roudi, O.M. and Mohamed, M.G.K. (2003) Chelation behavior of nitrosopyrazolones with $\mathrm{Mn}(\mathrm{II}), \mathrm{Co}(\mathrm{II}), \mathrm{Ni}(\mathrm{II}), \mathrm{Cu}(\mathrm{II})$ and $\mathrm{Zn}(\mathrm{II})$, Journal of Thermal Analysis and Calorimetry, 73(3), 939-950.

[15] Abdel-Latif, S.A. (2001) Synthesis and characterization of some 3-phenyl-4-arylazo-5-pyrazolones with $\mathrm{La}$ (III), $\mathrm{Ce}(\mathrm{III}), \mathrm{Th}(\mathrm{IV})$ and $\mathrm{UO}_{2}(\mathrm{VI})$ complexes. Synthesis and Reactivity in Inorganic and Metal-Organic Chemistry, 31(8), 1355-1374.

[16] Hassib, H.B. and Abdel-Latif, S.A. (2003) Potentiometric, spectrometric thermal and conductimetric studies on some 3-phenyl-4-(arylazo)-5-pyrazolones and their complexes with divalent cobalt metal ion. Spectrochimica Acta Part A, 59(11), 2425-2434.

[17] El-Inany, G.A., El-Wahab, S.A. and Issa, Y.M. (1982) Spectrophotometric studies on some 1-phenyl-3methyl-4-arylhydrazone-5-pyrazolones and their complexes with some divalent transition metal ions. Egyptian Journal of Chemistry, 25(2), 101-105.

[18] Wentworth, W.E. and Becker, R.S. (1962) Potential method for the determination of electron affinities of molecules: Application to some aromatic hydrocarbons Journal of the American Chemical Society, 84(22), 4263-4266.

[19] Becker, R.S. and Wentworth, W.E. (1963) Electron affinities and ionization potentials of aromatic hydrocarbons. Journal of the American Chemical Society, 85(15), 2210-2214.

[20] Weat, D.C. (1970) Hand book of chemistry and physics. 50th Edition, The Chemical Rubber Company, Ohio,
969.

[21] Macdonald, A.M.G. and Sirichanya, P. (1969) The determination of metals in organic compounds by oxygen-flask combustion or wet combustion. Microchemical Journal, 14(2), 199-206.

[22] Temel, H., Cakir, Ü., Otludil, B. and Ugras, H.I. (2001) Synthesis, spectral and biological studies of $\mathrm{Mn}(\mathrm{II})$, $\mathrm{Ni}(\mathrm{II}), \mathrm{Cu}(\mathrm{II})$, and $\mathrm{Zn}(\mathrm{II})$ complexes with a tetradentate Schiff base ligand. Complexation studies and the determination of stability constants $(\mathrm{Ke})$. Synthesis and Reactivity in Inorganic and Metal-Organic Chemistry, 31(8), 1323-1337.

[23] El-Shazly, R.M., Al-Hazmi, G.A.A., Ghazy, S.E., El-Shahawi, M.S. and El-Asmy, A.A. (2005) Spectroscopic, thermal and electrochemical studies on some nickel (II) thiosemicarbazone complexes. Spectrochimica Acta Part A, 61(1-2), 243-252.

[24] Greeg, S.J. (1962) Surface chemistry of solids, Chapman and Hall, London.

[25] West, D.X. and Kohrman, R.E. (1979) 2-Acetylpyridine $\mathrm{N}$-oxide complexes of various lanthanide(III) ions. Journal of Inorganic and Nuclear Chemistry, 41(11), 1569-1571.

[26] West, D.X., Kohrman, R.E. (1979) Methyl substituted 2-picolinamine N-oxide complexes of copper(II). Journal of Inorganic and Nuclear Chemistry, 41(4), 477-480.

[27] Speca, A.N., Karayanis, N.M. and Pyltewski, L.L. (1974) Chromium (III) and iron (III) perchlorate with the mono-N-oxides of 2,2'-bipyridine and 1,10-phenanthroline. Inorganica Chimica Acta, 9(C), 87-93.

[28] Lever, A.B.P. (1984) Inorganic electronic spectroscopy. 2nd Edition, Elsevier, Amsterdam.

[29] El-Asmy, A.A. and Mounir, M. (1988) Electrical conductivity, spectral and magnetic properties of some transition metal complexes derived from dimedone bis (4-phenylthiosemicarbazone). Transition Metal Chemistry, 13(2), 143-145.

[30] Moawad, M.M. (2002) Complexation and thermal studies of uric acid with some divalent and trivalent metal ions of biological interest in the solid state. J. Coord. Chem., 50(1), 61-78. 